\title{
THE VENEREAL DISEASES SCHEME IN ENGLAND AND WALES IN I938
}

BELOw, in accordance with our custom in recent years and by permission of the Controller of H.M. Stationery Office, we have reprinted the section on Venereal Diseases in the Annual Report of the Chief Medical Officer of the Ministry of Health for the year I938.

The report contains evidence of a further decrease - in the incidence of fresh syphilis in England and Wales. It contains also interesting evidence to the effect that the anti-syphilitic treatment administered to men during the last war must have prevented the development of a substantial amount of cardio-vascular syphilis and, by inference from this, of late neuro-syphilis. The evidence is contained in the contrast between the increase in death rates for aneurysm in males with that in females. Probably most males who contracted syphilis in the last war received the treatment that was customary in the Services to which they belonged; probably most females went untreated, as the Civilian V.D. Service was then only in its infancy. The figures are perhaps more impressive when presented as standardised death rates, as shown in Table I of this introduction, derived from the RegistrarGeneral's Statistical Review for I936 (Text).

TABLE I.-Standardised Mortality per million living from Syphilis and Diseases of Syphilitic Origin.

\begin{tabular}{|c|c|c|c|c|c|c|c|c|}
\hline Males. & $1911-20$ & $x 922$. & 1927. & 1932. & 1933. & $x 934$. & 1935. & 1936 \\
\hline Syphilis . & 68 & 50 & 45 & 39 & 39 & 36 & 37 & 35 \\
\hline Tabes Dorsalis & 29 & 29 & 26 & 23 & $2 \mathrm{I}$ & I7 & 19 & I 7 \\
\hline G.P.I. . & 86 & 65 & 54 & 35 & $3 \mathrm{I}$ & 32 & 28 & 25 \\
\hline Aneurysm & $4^{2}$ & 36 & 36 & 36 & 35 & 36 & 36 & 37 \\
\hline Total & 225 & I8o & I6I & I33 & I 26 & I 21 & 120 & I I 4 \\
\hline \multicolumn{9}{|l|}{ Females. } \\
\hline Syphilis . & 48 & 37 & 29 & 23 & $2 \mathrm{I}$ & I 8 & I6 & I6 \\
\hline Tabes Dorsalis & 5 & 5 & 5 & 5 & 4 & 3 & 4 & 3 \\
\hline G.P.I. & I7 & I3 & II & 9 & 9 & 8 & 9 & 8 \\
\hline Aneurysm & 9 & 8 & 9 & I I & I3 & I 3 & I 4 & I6 \\
\hline Total & 79 & 63 & 54 & 48 & 47 & 42 & 43 & 43 \\
\hline
\end{tabular}




\section{BRITISH JOURNAL OF VENEREAL DISEASES}

This shows that whereas the mortality from aneurysm in males from 1922 to 1936 did not change significantly, that in females doubled.

The rate for syphilis was formerly made up chiefly of deaths under five years of age but the distribution has changed as is shown in Table 2, the figures in which have been taken from the Registrar-General's Statistical Review for 1928 (Text).

TABLE 2.-Standardised Mortality from Syphilis in England and Wales at all ages and with distinction of those occurring in childhood (0-5) and in Later Life.

\begin{tabular}{|c|c|c|c|c|c|c|c|c|c|c|}
\hline Males. & I9II. & 1914. & 1917. & 1922. & 1923. & 1924. & 1925. & 1926. & 1927. & $\mathbf{r} 928$. \\
\hline All ages & 60 & $7 \mathbf{I}$ & 74 & $5^{\circ}$ & 48 & 42 & 39 & 43 & 45 & 50 \\
\hline Under 5 & 39 & 50 & $5^{2}$ & 35 & 33 & 26 & 24 & 26 & 22 & $2 I$ \\
\hline Over 5 & 21 & $2 \mathrm{I}$ & 22 & 15 & 15 & I6 & I5 & 17 & 23 & 29 \\
\hline \multicolumn{11}{|l|}{ Females. } \\
\hline All ages & 45 & $5^{2}$ & $5^{2}$ & 37 & 30 & 28 & 25 & 26 & 29 & 28 \\
\hline Under 5 & 33 & 39 & $4^{I}$ & 28 & 23 & 20 & 17 & 17 & I7 & I5 \\
\hline Over 5 & I 2 & I3 & II & 9 & 7 & 8 & 8 & 9 & 12 & 13 \\
\hline
\end{tabular}

The figures are admittedly an under-statement, and it is interesting to note that the rises in 1927 and 1928 were attributed by the Registrar-General to the introduction, in the middle of 1927 , of confidential certification. The table shows a steady reduction in the rate for children under the age of five. This has continued and now the greater part of the mortality is attributable to deaths of persons over five years of age. This can be understood from the fact that, according to the RegistrarGeneral's Statistical Review for I936, in the years I93I-36 the deaths classed to congenital syphilis totalled 4I2, $365,296,261,239$ and 220 respectively, while those attributed to acquired syphilis totalled I,034, 938, I,025, $973, \mathrm{I}, 003$ and 983 . The figures quoted, which indicate a great decline in congenital syphilis, support those in Tables D and E of the C.M.O.'s Report.

The section on measures that are advised in the event of war have now unfortunately become of greater practical interest than when the report was written.

Here follows the Report. 


\section{ANNUAL REPORT OF THE CHIEF MEDICAL OFFICER, MINISTRY OF HEALTH}

\section{Venereal Diseases}

THE experience of the year I938 strengthened the hope that the new chemotherapy of bacterial infections may eventually prove to be as effective in preventing the spread of gonorrhoea as the arsphenamine compounds have been in syphilis. The sulphonamide treatment of gonorrhœa is discussed in more detail below (p. 72).

\section{Treatment Centres.}

The number of treatment centres in England and Wales at the close of 1938 was 187 . The centre at Faversham was closed in August, I938, owing to its ceasing to be required. The centre at Walsall was transferred from the General Hospital to the Manor Hospital administered by the County Borough Council, and that at Bolton was moved to new premises at the Civic Centre. New centres were opened at the Essex County Council's Oldchurch Hospital, Romford, and at the Harrogate and District General Hospital. In each of these cases the new premises were designed in consultation with medical officers of the Ministry of Health.

The Incidence of Venereal Diseases in England AND WALES

Syphilis.-The returns from the treatment centres showed that in the year 1938 the number of cases of syphilis with infections of less than one year's duration dealt with there for the first time (Appendix G, Table C) was less by 395 (males 242, females I53) than in I937, a decline (approximately) of 7 per cent. The number of early infections was over 42 per cent. less than in I93I, the first year in which figures relating to infections of less than one year's duration were separately recorded. The number of old plus new infections dealt with for the first time in 1938 (Appendix G, Table B) was over 33 per cent. less than in 1925 and over 29 per cent. less than in I93I; since the latter year the decline in both old and fresh infections dealt with for the first time at the centres has been practically continuous.

Cases of congenital syphilis dealt with at the treatment centres (Appendix G, Table D) were 9r fewer than in 1937 and $70 \mathrm{I}$, or approximately 29 per cent., fewer than in 
I93I. The falls in the numbers of these cases which have taken place since I93I have been in the groups under I5 years of age. Thus, in cases under one year the fall was over 36 per cent., in children aged one and under five it was approximately 40 per cent., and in those aged five and under $I_{5}$ it was over 54 per cent.

The fact that there has been a substantial fall in the number of cases aged five and under I5 years seems to suggest that falls in the numbers of cases under one year of age in previous years have not been due merely to cloaking of symptoms by a little antenatal treatment. In the group aged I5 years and over there has been a small increase, of 29 cases, over the number recorded in I93I, but this may be accounted for by an increase in the incidence of congenital syphilis in the war of I9I4-I8 and immediately succeeding years; the occurrence of such an increase is suggested by the relatively high death rates, in those years, of infants under one year of age certified as due to syphilis, which ranged from $\mathrm{I} \cdot 44$ to $2 \cdot 03$ per I,000 live births, or from seven to ten times the corresponding rate of 0.20 in 1938. As will be seen in Table $\mathrm{E}$, this rate has declined steadily from the peak in I9I7.

Deaths from general paralysis of the insane (Appen$\operatorname{dix} \mathrm{G}$, Table $\mathrm{F}$ ) increased by 34 in males and decreased by 38 in females. Deaths from tabes dorsalis (locomotor ataxia) increased by one in males, to 474 , and in females were the same as in 1937. Deaths from aneurysm (Appendix G, Table G) increased by 23 in each sex. The changes in rates of mortality from these three late effects of syphilis since 1922 shows some interesting features.

In general paralysis of the insane the crude death rate per million of the male population fell almost continuously from 77 in I922 to 32 , or less than half, in I938. On the other hand, in females the rate, though generally much lower than in males, fell more slowly, namely from ${ }_{5} 5$ in I 922 to Io in I938. In tabes the rates for both sexes fell on the whole much more slowly than did that of deaths from general paralysis in males, the figures from 1922 to I938 showing declines from 36 to 24 in males and from 7 to 5 in females. In aneurysm the rates increased in both males and females, and the difference between the two sexes in respect of changes in rates was far more 


\section{VENEREAL DISEASES SCHEME}

striking than in either of the other two late effects of syphilis first mentioned. Thus, in males the rate increased from 45 in 1922 to 52 in I938, but that for females, from II in 1922 to 26 , or nearly two and a half times, in I938.

The greater rate of decline in the death rate from general paralysis for males than in that for females is probably due to application of more efficient antisyphilitic treatment, both in the early stages of the disease and later in those cases which eventually became paretic. Deaths from general paralysis of the insane, tabes and aneurysm in recent years are mostly a result of syphilis contracted during the war and immediately succeeding years, when most young men were serving in the armed forces and much more likely to be brought under treatment than their contemporaries of the opposite sex. In those cases which eventually develop signs of neuro-syphilis it seems probable that men with these late manifestations of syphilis, on account of their domestic responsibilities, larger number of dependants, etc., come sooner to medical notice than women so affected. Consequently, men probably receive pyrogenetic and other treatment suitable for such late effects at an earlier stage of the disease than do women. The death rate from aneurysm is much less likely to be affected by later treatment than is that from neuro-syphilis, and is therefore more clearly dependent on rates of infection in earlier years, and on efficiency of treatment in the early stages of the disease. It emphasises the importance of maintaining an efficient venereal diseases service in time of war, and, particularly, of sparing no effort to secure the treatment of infected women.

Gonorrhoea.-The cases dealt with for the first time in I938 (Appendix G, Table B) were 27,947 males and 7,746 females, of which 26,448 males and 6,75I females had infections of less than one year's duration. The figures show a reduction of over I,O0O in the males with early infections, but this may be due to a larger proportion of the infected having been treated privately by practitioners, encouraged by the relative ease with which the symptoms of the disease can be controlled by sulphonamide treatment. In Wales, compared with I937, the number of new cases of gonorrhœa included in the above figures, declined from 2,537 to 2,392 . 
Attendances.-The figures in Table A, Appendix G, show that from the start of the venereal diseases scheme the number of attendances at the centres increased steadily (except for a slight fall over the years 1922 and 1923) until 1934, when they reached a peak of 3,407,000, after which they declined and were over 64,000 fewer in 1937; in 1938 they decreased further by over 223,000. A closer analysis of the figures showed, as was expected, that the very substantial fall in 1938 was in attendances by patients with gonorrhœa. The total attendances for consultation with medical officers $(I, 502,238)$ were actually about 6,000 more than in I937, but those by patients with gonorrhœa were nearly I8,000 fewer, and attendances for intermediate treatment of gonorrhœa fell by nearly 227,000. The cause is attributable to the new chemotherapy of gonorrhœa. The lessened demand for intermediate treatment must affect the planning of treatment centres since the number of irrigation cubicles and of cubicles for intermediate treatment of women can be reduced considerably.

\section{The Sulphonamide Treatment of Gonorrhoa}

From the standpoint of preventive medicine it is encouraging to record that experience of treatment of gonorrhœa with the sulphonamide group of remedies has continued to support their earlier promise of eventually proving a most valuable weapon against the spread of this disease. Numerous published reports have agreed in showing that under this form of treatment the duration of active symptoms in the majority of cases is reduced from some weeks to a comparatively few days, and any complications such as gonorrhœal ophthalmia, epididymitis and arthritis are brought rapidly under control.

The benefits are likely to prove highly important. Apart from the fact that blindness, crippling from arthritis, ill-health from pelvic complications in women and similar grave effects causing permanent suffering and invalidity are likely to diminish very greatly, vulvo-vaginitis of children and its attendant domestic distress promise also to become a relatively minor problem. Furthermore, the new treatment must reduce considerably the work per average case of gonorrhœa in respect of intermediate treatment and nursing of in-patients; evidence of the 


\section{VENEREAL DISEASES SCHEME}

effect which the treatment has already had on intermediate treatment has been given above (see p. 7I).

Desirable precautions in the use of sulphonamide preparations.It seems probable that for some time there may be no material reduction of work per case in respect of detailed examinations. In cases which do not respond to sulphonamide therapy, or repeatedly relapse after it, careful examination to determine whether or not the cause lies in badly draining foci will occupy much time, and the same applies to tests of cure. Careful observers appear to agree that sulphonamide treatment of gonorrhoea may deceive by eliminating symptoms without eradicating the disease; hence, tests of cure have to be particularly strict.

There is a risk, also, that through unskilled use of the sulphonamide remedies there may be temporarily an actual increase in the incidence of gonorrhœa. The common effect of a few days' treatment with one of these remedies is to rid the patient of discharge and all feelings of discomfort. In such circumstances many patients, imagining themselves to be cured, may resume their sexual habits and spread the disease ; it is most important, therefore, that those who use these remedies should learn their limitations. Unfortunately, there is evidence that many private practitioners who have been tempted by the apparent ease of sulphonamide therapy to undertake the cure of cases of gonorrhœea have not appreciated the importance of a sufficient dosage and of great strictness in tests of cure. Large numbers of cases of gonorrhœa are being treated with inadequate amounts of the new remedies and are being allowed to believe themselves cured when in reality they have only become symptomless gonococcuscarriers. For these reasons it is earnestly to be hoped that private practitioners will avail themselves fully of the provision under the venereal diseases scheme for free consultation with medical officers of venereal diseases treatment centres. They can learn from them the latest developments of this form of therapy, and also the best methods of testing for cure.

\section{Anti-venereal Measures in the Event of War}

Of necessity a state of war increases considerably the strain on anti-venereal organisation. Venereal disease has been termed " the camp follower of war," and it may be readily understood how war circumstances would, unfortunately, favour the spread of venereal diseases. The general state of heightened nervous tension and excitement in persons lacking in self-control increases sexual promiscuity, and the shifting of large numbers of people to areas hitherto sparsely populated may be associated with outbreaks of venereal diseases in places unprovided with treatment facilities. For these reasons 


\section{BRITISH JOURNAL OF VENEREAL DISEASES}

it would probably become necessary for county councils and county borough councils in some places to expand existing centres and in others to set up additional ones to cope with outbreaks in places from which infected persons could not attend existing centres except at great inconvenience; at the same time transport of civilians would probably be much reduced, and existing centres could not be expected to serve such wide areas as at present.

On the other hand, war exigencies would tend to deplete the staffs of venereal diseases treatment centres by removal of personnel for other duties; this will readily be understood from the fact that many medical officers in these treatment centres are not exclusively specialists in venereal diseases and might well be required for other branches of medicine.

Since it is impossible to determine with any great accuracy in advance where gaps in the present service would occur or where new facilities would be needed, it is suggested that the best way of meeting the difficulty would be to form mobile units each consisting of a specialist in venereal diseases, nurse, orderly and, perhaps, clerk with a motor vehicle containing a full equipment for dealing efficiently with venereal diseases. Such a unit would take over the work of any existing centre which had been left without personnel, if the gaps could not be filled from local resources; it could, also, afford facilities for treatment in new places, where outbreaks of venereal diseases had occurred, and the distance to the nearest centre was so great that those infected could not attend it regularly. The actual work of diagnosis and treatment in the new places would be in the most suitable buildings the medical officer could obtain. As in the case of existing facilities, it seems probable that neighbouring county authorities would find it convenient to share in the services of one or more units of this kind.

Laboratory assistance in the diagnosis of Venereal Diseases.

The number of tests of specimens examined under the venereal diseases scheme in the approved laboratories and the treatment centres are shown in Appendix G, Table $\mathrm{H}$; the total was 888, 157 , of which II2,377 were microscopical tests carried out by clinicians in the treatment centres.

Of the 775,780 tests in approved laboratories, 535,166 were for treatment centres, 193,826 for hospitals and other institutions 


\section{VENEREAL DISEASES SCHEME}

and 46,788 for private practitioners. There were again fairly substantial increases in the numbers of flocculation tests and in tests of cerebrospinal fluid.

\section{Comparison of Serum Tests.}

During the year the comparisons of methods of the Wassermann test for syphilis employed in approved laboratories with tests by the method described in the Medical Research Council's Special Report Series No. I29 were resumed, the tests being made by Dr. Richardson in the laboratory of the Ministry of Health in parallel with those by collaborating pathologists in a number of approved laboratories.

Nine comparisons each on 200 specimens, were completed and seven were in progress at the end of the year.

\section{APPENDIX G}

England and Wales: Tables relating to Venereal Diseases.

TaBle A

\begin{tabular}{|c|c|c|c|c|c|c|c|c|}
\hline \multirow{2}{*}{ Year. } & \multicolumn{6}{|c|}{$\begin{array}{l}\text { Number of Cases in all Stages, dealt with for the first time at } \\
\text { the Treatment Centres* }\end{array}$} & \multirow{2}{*}{$\begin{array}{c}\text { Total } \\
\text { Number of } \\
\text { Attendances }\end{array}$} & \multirow{2}{*}{$\begin{array}{c}\text { Number o } \\
\text { Treatment } \\
\text { Centres } \\
\text { at end of } \\
\text { Year. }\end{array}$} \\
\hline & Syphilis. & $\begin{array}{c}\text { Soft } \\
\text { Chancre. }\end{array}$ & Gonorrhœa. & $\begin{array}{l}\text { Total } \\
\text { V.D. }\end{array}$ & $\begin{array}{l}\text { Other } \\
\text { than } \\
\text { V.D. }\end{array}$ & Total. & & \\
\hline 1917 & - & 一 & - & 一 & - & 29,036 & 204,692 & I I 3 \\
\hline 1918 & 26,912 & 806 & I 7,635 & 45,353 & 6,622 & $5^{1,975}$ & 488, I 37 & I34 \\
\hline 1919 & 42, I 34 & 2,164 & 38,499 & 82,797 & I 5,447 & 98,244 & $\mathrm{I}, 002,79 \mathrm{I}$ & 160 \\
\hline 1920 & 42,805 & $2,44^{2}$ & 40,284 & 85,531 & I 9,654 & 105,185 & $\mathrm{I}, 488,5 \mathrm{I} 4$ & 190 \\
\hline 1921 & 32,733 & $I, 654$ & 32,433 & 66,820 & I 7,459 & 84,279 & $1,612,592$ & 194 \\
\hline 1922 & 25,762 & I, 108 & 29,477 & 56,347 & I 6,988 & 73,335 & $1,560,568$ & I9I \\
\hline 1923 & 23,927 & I, I IO & 30,908 & 55,945 & I 7,668 & 73,613 & $1,605,617$ & 192 \\
\hline 1924 & 22,010 & I, 098 & 31,272 & 54,380 & I 8,842 & 73,222 & $\mathrm{x}, 645,4 \mathrm{I} 5$ & 193 \\
\hline 1925 & $22,5^{88}$ & I, 106 & $33,4^{6} 3$ & 57, I 57 & 21,053 & 78,2 Io & $\mathrm{I}, 7 \mathrm{I} 9, \mathbf{1} 48$ & 193 \\
\hline 1926 & $22,55^{\circ}$ & $\mathrm{I}, \mathrm{I} 5^{\mathrm{O}}$ & $35,05^{2}$ & $5^{8}, 75^{2}$ & 22,754 & $8 \mathrm{I}, 506$ & $2,008,063$ & I90 \\
\hline 1927 & 23,395 & 1,063 & 38,242 & 62,700 & 25,436 & 88, I 36 & $2,179,707$ & I 86 \\
\hline 1928 & 22,761 & 1,138 & 42,032 & 65,931 & 28,029 & 93,960 & $2,422,749$ & I 88 \\
\hline 1929 & 22,019 & I, 298 & $44, I 66$ & 67,483 & 27,980 & 95,463 & $2,604,217$ & 188 \\
\hline 1930 & 23,120 & 1,324 & 45,001 & 69,445 & $3 \mathrm{I}, \mathrm{IO} 4$ & IOO, 549 & $2,817,195$ & I90 \\
\hline 1931 & 22,934 & 1,163 & 42,460 & 66,557 & $3 I, 82 I$ & 98,378 & $2,992,76 \mathrm{I}$ & 189 \\
\hline 1932 & 22,215 & $95^{2}$ & $4^{I}, 25^{I}$ & 64,418 & 32,997 & 97,4 I 5 & $3,109,174$ & I 88 \\
\hline 1933 & $21,5^{2} 5$ & 926 & 43,226 & 65,677 & 32,767 & 98,444 & $3,252,323$ & I 86 \\
\hline I 934 & 20,692 & 960 & 43,391 & 65,043 & 36,3 I I & IOI,354 & $3,407,000$ & I 84 \\
\hline 1935 & 19,335 & I, I I 2 & 41,332 & 61,779 & 36,230 & 98,009 & $3,398,678$ & 185 \\
\hline $193^{6}$ & I8,609 & I,, 000 & 42,230 & 61,839 & 36,719 & $98,55^{8}$ & $3,360,328$ & 186 \\
\hline I 937 & I9, I 85 & $94^{I}$ & 43,802 & 63,928 & $38,59 I$ & 102,519 & $3,34^{2,571}$ & I 86 \\
\hline $193^{8}$ & 18,034 & 1,007 & $4 I, 759$ & 60,800 & 41,487 & 102,287 & $3,119,331$ & I 87 \\
\hline
\end{tabular}

* Includes cases transferred from centre to centre and those that returned after being struck off the books in previous years. 
TABLE B.-Number of Cases (in all stages) dealt with for the first time at any Centre.*

\begin{tabular}{|c|c|c|c|c|c|c|c|}
\hline \multicolumn{4}{|c|}{ Year. } & Syphilis. & Soft Chancre. & Gonorrhœea. & Total V.D. \\
\hline 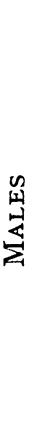 & $\begin{array}{l}1925 \\
1926 \\
1927 \\
1928 \\
1929 \\
1930 \\
1931 \\
1932 \\
1933 \\
1934 \\
1935 \\
1936 \\
1937 \\
1938\end{array}$ & $\begin{array}{l}\dot{.} \\
. \\
. \\
. \\
. \\
. \\
. \\
. \\
. \\
. \\
. \\
.\end{array}$ & 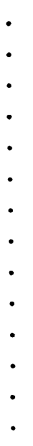 & $\begin{array}{r}\text { I I }, 782 \\
\text { I } 2, \text { I I } 8 \\
\text { I } 2,393 \\
\text { I } 2,05 \text { I } \\
\text { I I }, 538 \\
\text { I I,967 } \\
\text { I I }, 285 \\
\text { I I ,032 } \\
\text { I0,738 } \\
9,6 \text { I } 5 \\
8,596 \\
8,224 \\
8,069 \\
7,832\end{array}$ & $\begin{array}{r}\mathrm{I}, \mathrm{O} 48 \\
\mathrm{I}, 070 \\
986 \\
\mathrm{I}, 053 \\
\mathrm{I}, 202 \\
\mathrm{I}, 244 \\
\mathrm{I}, 042 \\
845 \\
826 \\
876 \\
\mathrm{I}, \mathrm{OI} \mathrm{I} \\
880 \\
824 \\
889\end{array}$ & $\begin{array}{l}24,398 \\
25,535 \\
28,195 \\
30,425 \\
31,8 \text { I0 } \\
32,217 \\
29,310 \\
28,179 \\
29,169 \\
28,787 \\
27,506 \\
28,137 \\
29,250 \\
27,947\end{array}$ & $\begin{array}{l}37,228 \\
38,723 \\
41,574 \\
43,529 \\
44,550 \\
45,428 \\
41,637 \\
40,056 \\
40,733 \\
39,278 \\
37, \text { I } 13 \\
37,241 \\
38,143 \\
36,668\end{array}$ \\
\hline 嵧 & $\begin{array}{l}1925 \\
1926 \\
1927 \\
1928 \\
1929 \\
1930 \\
1931 \\
1932 \\
1933 \\
1934 \\
1935 \\
1936 \\
1937 \\
1938\end{array}$ & $\begin{array}{l}\dot{.} \\
\dot{.} \\
\dot{.} \\
\dot{.} \\
\dot{.} \\
\dot{.} \\
\dot{.} \\
\dot{.} \\
\dot{.}\end{array}$ & $\begin{array}{l}\dot{.} \\
\dot{.} \\
\dot{.} \\
\dot{.} \\
\dot{.} \\
\dot{.} \\
\dot{.} \\
\dot{.} \\
\dot{.} \\
\dot{.}\end{array}$ & $\begin{array}{l}7,385 \\
7,133 \\
7,553 \\
7,090 \\
6,586 \\
6,916 \\
6,827 \\
6,461 \\
6,029 \\
5,838 \\
5,565 \\
5,128 \\
5,165 \\
4,986\end{array}$ & $\begin{array}{l}27 \\
21 \\
20 \\
28 \\
22 \\
17 \\
20 \\
29 \\
22 \\
10 \\
16 \\
29 \\
15 \\
15\end{array}$ & $\begin{array}{l}6,120 \\
6,416 \\
6,809 \\
7,810 \\
7,798 \\
7,939 \\
7,697 \\
7,677 \\
8,583 \\
8,199 \\
7,732 \\
7,715 \\
7,787 \\
7,746\end{array}$ & $\begin{array}{l}\text { I } 3,532 \\
\text { I } 3,570 \\
\text { I } 4,382 \\
\text { I } 4,928 \\
\text { I } 4,406 \\
\text { I } 4,872 \\
\text { I } 4,544 \\
\text { I } 4,167 \\
\text { I } 4,634 \\
\text { I } 4,047 \\
\text { I } 3,3 \text { I } 3 \\
\text { I } 2,872 \\
\text { I } 2,967 \\
\text { I } 2,747\end{array}$ \\
\hline
\end{tabular}

* Excludes cases transferred from centre to centre and those that returned with the same infections after being struck off the books in previous years.

TABLE C.-Cases of acquired Syphilis in Table B, with infections of less than one year.

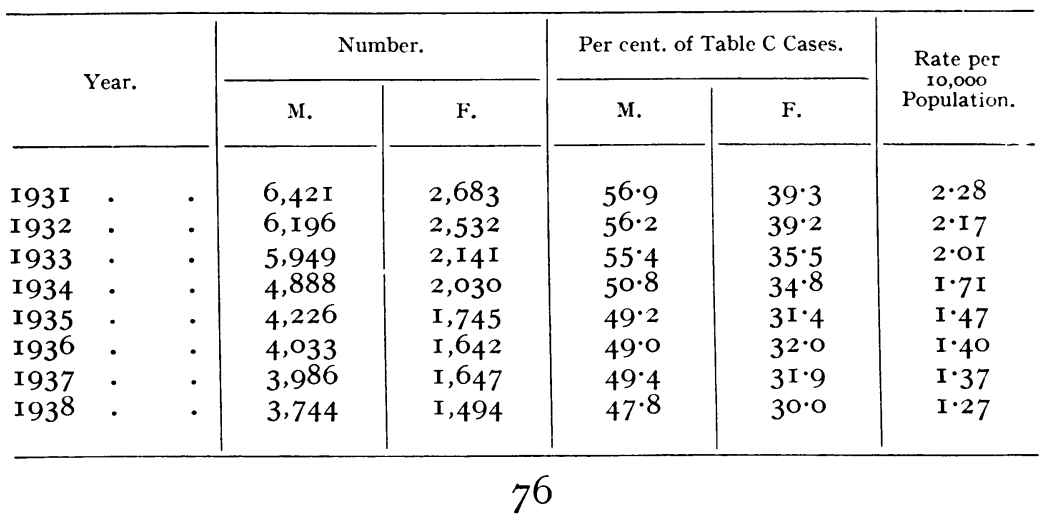




\section{VENEREAL DISEASES SCHEME}

TABLE D.-Cases of Congenital Syphilis dealt with for the first time at the Treatment Centres.

\begin{tabular}{|c|c|c|c|c|c|c|c|}
\hline \multicolumn{3}{|c|}{ Year. } & Under I Year. & $\begin{array}{l}\text { I and under } \\
5 \text { Years. }\end{array}$ & $\begin{array}{l}5 \text { and under } \\
\text { I5 Years. }\end{array}$ & $\begin{array}{l}\text { I5 Years and } \\
\text { Over. }\end{array}$ & Totals. \\
\hline I93I & - & . & 339 & 204 & 974 & 922 & 2,439 \\
\hline 1932 & . & . & 302 & I80 & 857 & 805 & 2,144 \\
\hline I933 & . & . & 305 & I 57 & 774 & 780 & 2,016 \\
\hline I934 & . & . & 296 & 165 & 708 & 839 & 2,008 \\
\hline I935 & . & . & $25^{I}$ & 165 & $67 \mathrm{I}$ & 944 & $2,03 \mathrm{I}$ \\
\hline 1936 & - & . & $24 I$ & 132 & 600 & 935 & $I, 908$ \\
\hline 1937 & - & . & 2 II & I 44 & 534 & 940 & 1,829 \\
\hline 1938 & . & . & 216 & I 23 & $44^{7}$ & $95 \mathrm{I}$ & $I, 73^{8}$ \\
\hline
\end{tabular}

TABLE E.-Death Rates per I,000 Live Births, of Infants under one Year certified as due to Syphilis. -Information extracted from the Registrar-General's Statistical Reviews.

\begin{tabular}{|c|c|c|c|c|c|c|c|c|c|c|}
\hline I9I 2 & . & - & - & - $\quad \mathrm{I} \cdot 34$ & 1926 & • & • & • & - & 0.84 \\
\hline 1913 & . & . & . & . $I \cdot 4^{6}$ & 1927 & $\cdot$ & • & • & 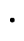 & $0 \cdot 77$ \\
\hline I9I 4 & . & . & - & - $\quad \mathrm{I} \cdot 55$ & I928 & • & • & • & - & 0.71 \\
\hline I9I 5 & . & . & . & . $\quad I \cdot 44$ & 1929 & - & . & . & • & 0.64 \\
\hline I9I 6 & . & . & . & . $\quad 1 \cdot 57$ & I930 & - & . & . & . & 0.55 \\
\hline I9I 7 & . & - & - & . 2.03 & I93I & - & - & - & - & $0.5 \mathrm{I}$ \\
\hline 1918 & . & . & . & - $\quad I \cdot 90$ & 1932 & - & - & - & - & 0.47 \\
\hline I9I9 & . & . & . & . $\quad \mathbf{I} \cdot 76$ & I933 & - & - & • & - & 0.40 \\
\hline 1920 & . & . & . & - $I \cdot 5^{I}$ & I934 & . & - & . & - & $0 \cdot 34$ \\
\hline I92 I & . & . & . & - $\quad I \cdot 43$ & I935 & . & - & - & • & 0.29 \\
\hline 1922 & . & . & . & - $I \cdot I 2$ & 1936 & . & - & . & - & $0 \cdot 27$ \\
\hline I923 & . & . & - & . $\quad \mathrm{I} \cdot \mathrm{O}_{5}$ & I937 & - & - & - & - & $0 \cdot 23$ \\
\hline 1924 & . & . & . & . $0.9 \mathrm{I}$ & I938 & - & - & - & - & $0 \cdot 20$ \\
\hline 1925 & . & . & . & . 0.82 & & & & & & \\
\hline
\end{tabular}


BRITISH JOURNAL OF VENEREAL DISEASES

Table F.-General Paralysis of the Insane and TABES DoRsalis

Deaths and Crude Annual Death Rates per million living.-Information extracted from the Registrar-General's Statistical Reviews.

\begin{tabular}{|c|c|c|c|c|c|c|c|c|}
\hline \multirow{3}{*}{ Year. } & \multicolumn{4}{|c|}{ General Paralysis of the Insane. } & \multicolumn{4}{|c|}{ Tabes Dorsalis. } \\
\hline & \multicolumn{2}{|c|}{ Males. } & \multicolumn{2}{|c|}{ Females. } & \multicolumn{2}{|c|}{ Males. } & \multicolumn{2}{|c|}{ Females. } \\
\hline & Actuals. & $\begin{array}{l}\text { Crude } \\
\text { Rate. }\end{array}$ & Actuals. & $\begin{array}{l}\text { Crude } \\
\text { Rate. }\end{array}$ & Actuals. & $\begin{array}{l}\text { Crude } \\
\text { Rate. }\end{array}$ & Actuals. & $\begin{array}{l}\text { Crude } \\
\text { Rate. }\end{array}$ \\
\hline I9II & 1,763 & IOI & 438 & 23 & 530 & 30 & 105 & 6 \\
\hline 1914 & 1,831 & 102 & 434 & 23 & 600 & 34 & 120 & 6 \\
\hline 1917 & $\mathrm{r}, 94^{\circ}$ & I 26* & 425 & 22 & $64 I$ & $45^{*}$ & I 6 & 6 \\
\hline 1922 & $\mathbf{I}, 398$ & 77 & 300 & I5 & 665 & 36 & 136 & 7 \\
\hline 1927 & 1,929 & 65 & 284 & I4 & 642 & 34 & 138 & 7 \\
\hline 1932 & 864 & 45 & 236 & II & 634 & 33 & 144 & 7 \\
\hline 1933 & 771 & 40 & 239 & I I & 592 & $3 I$ & $I_{4} I$ & 7 \\
\hline 1934 & 788 & $4^{I}$ & 224 & I I & 496 & 26 & 107 & 5 \\
\hline 1935 & 725 & 37 & 240 & I I & 553 & 28 & I 18 & 6 \\
\hline 1936 & $65^{2}$ & 33 & 232 & I I & 496 & 25 & IO4 & 5 \\
\hline I937 & 594 & 30 & 253 & 12 & 473 & 24 & 116 & 5 \\
\hline $193^{8}$ & 628 & 32 & $2 I_{5}$ & Io & 474 & 24 & I 16 & 5 \\
\hline
\end{tabular}

* Based on civilian deaths and civilian population.

\section{TABLE G.-AnEurysm}

Deaths and Crude Annual Death Rates per million living.-Information extracted from the Registrar-General's Statistical Review.

\begin{tabular}{|c|c|c|c|c|c|c|c|}
\hline \multirow{3}{*}{\multicolumn{2}{|c|}{ Year. }} & \multicolumn{2}{|c|}{ Population. } & \multicolumn{4}{|c|}{ Aneurysm. } \\
\hline & & \multirow{2}{*}{ Males. } & \multirow{2}{*}{ Females. } & \multicolumn{2}{|c|}{ Males. } & \multicolumn{2}{|c|}{ Females. } \\
\hline & & & & Actuals. & $\begin{array}{l}\text { Crude } \\
\text { Rates. }\end{array}$ & Actuals. & $\begin{array}{l}\text { Crude } \\
\text { Rates. }\end{array}$ \\
\hline I9I I & - & $\mathrm{I} 7,503,377$ & I8,686,308 & 935 & 53 & 225 & 12 \\
\hline 1914 & - & $17,877,052$ & $x_{9}, 08_{3}, 6_{32}$ & 902 & 50 & 229 & I 2 \\
\hline 1917 & . & $14,085,300 *$ & $19,625,700 *$ & $77^{\circ}$ & $5 \mathrm{I} \dagger$ & 225 & II \\
\hline 1922 & . & $18,038,000$ & $19,933,000$ & 825 & 45 & 217 & I I \\
\hline 1927 & . & $\mathrm{r} 8,804,000$ & $20,486,000$ & 885 & 47 & 270 & 13 \\
\hline $193^{2}$ & . & I9,280,000 & $20,921,000$ & $95^{8}$ & 50 & 336 & 16 \\
\hline 1933 & . & $19,357,000$ & $20,993,000$ & $93 I$ & 48 & $4 I_{4}$ & 20 \\
\hline 1934 & - & $19,412,000$ & $21,055,000$ & 984 & $5^{I}$ & $43^{I}$ & 20 \\
\hline I935 & . & $19,500,000$ & $2 \mathrm{I}, \mathrm{I} 45,000$ & 982 & $5^{\circ}$ & 459 & 22 \\
\hline 1936 & . & I9,59I,000 & $2 \mathrm{I}, 248,000$ & $\mathrm{I}, 030$ & 53 & 490 & 23 \\
\hline 1937 & . & $19,705,000$ & $21,326,000$ & I,OOI & $5 I$ & 528 & 25 \\
\hline 1938 & . & I9,792,000 & $21,423,000$ & $\mathrm{I}, 024$ & 52 & $55^{\mathrm{I}}$ & 26 \\
\hline
\end{tabular}

* Civilian population only.

$\uparrow$ Based on civilian deaths and civilian population.

$$
78
$$




\section{VENEREAL DISEASES SCHEME}

TABLE H.-Examinations of Specimens. - (a) In Approved Laboratories, (b) In V.D. Treatment Centres.

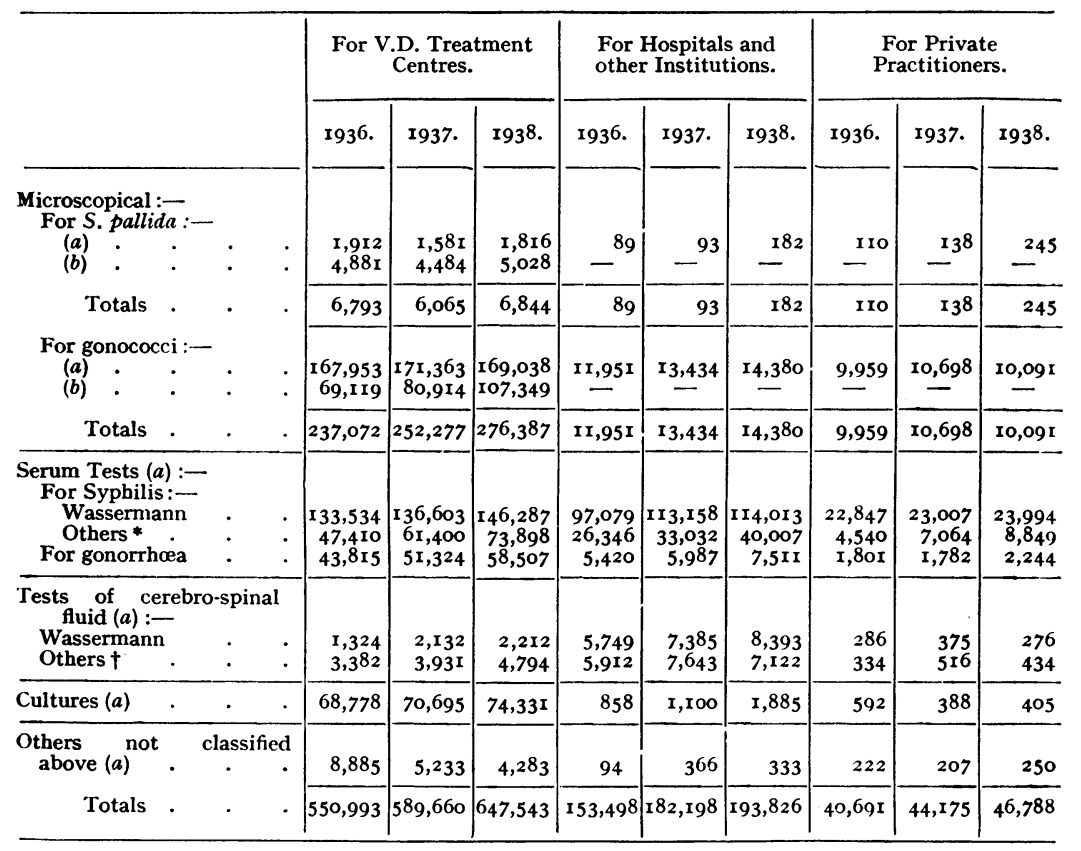

* Kahn, Meinicke, Müller-Ballungs, Sigma, Vernes, etc., always applied in addition to the Wassermann.

$\dagger$ Cell count, globulin, colloidal, protein, sugar, Kahn, Sigma, etc., practically alway's in addition to the Wassermann. 